\title{
MODELING OF FLUIDIZATION AND PRESSURE DROP OF MODIFIED TITANIUM WHITE USING ANASYS / CFX - FLUENT IN METALURGICAL PROCESSES
}

\author{
Aleš PROCHÁZKA, Aleš SLÍVA, Robert BRÁZDA \\ VSB - Technical University of Ostrava, Ostrava, Czech Republic, EU, \\ ales.sliva@vsb.cz
}

https://doi.org/10.37904/metal.2021.4251

\begin{abstract}
The paper sets an example of modeling the expansion and bed pressure drop of the cohesive and problematic material - titanium dioxide modified by Aerosil R972 in program Ansys / CFX - Fluent using two multiphase models, Euler Fluid-Granular Model and Dense Discrete Phase Model at certain predefined conditions in a square section fluidized bed cell. The variables bed pressure drop, particle concentration in volume and velocity field of solid particles were defined for the simulations in metallurgical processes.

The research follows on from the previous study of simulating the arrangement of spherical particles with a diameter of 2-10 $\mathrm{mm}$ and compares them with the experiment, where it was discovered, that the square section fluidized cell achieves the best results with spherical particle arrangements of diameter $8 \mathrm{~mm}$.
\end{abstract}

Keywords: Titanium white, fluidized bed, pressure drop, Ansys / CFX - Fluent

\section{INTRODUCTION}

Titanium dioxide is a chemical compound of titanium and oxygen. Normally, its naturally contaminated form by other metal ions appears in several mineral forms, its artificially created counterpart is called Titanium White $[1,2]$.

Titanium dioxide is utilized mainly in the form of pigment in paints for its distinctive brightness and refractive index (reported $n=2.7$ in the literature [3]), in the food industry in the form of a dye as catalyst. Other uses of titanium white can be found in optics in the form of a suitable material in the manufacture of dielectric mirrors, as a thin film from this material, utilized for its high reflectivity, color fastness, whiteness, opacity, and the so on.

These properties can also be exploited for dyeing in the form of pigment for use in plastics, paper, food, pharmaceuticals, etc. Its other important feature is also hydrophobia, which is applied in a wide range of process industries of various materials and products. In the automotive industry its use can see in the production of glass and catalysts for its good antioxidant abilities and in the field of disinfection and selfcleaning substances, especially in coatings (formation of nanostructures with a lasting effect [4]). More recently, it has been used in photovoltaics for power generation and as a material suitable for the ability to 'purify air' due to its photocatalytic properties.

Titanium white, due to its granulometric composition, and by the effect of interparticular forces causes problematic behavior in transport, handling and storage systems. An effective tool to improve these properties is the process treatment of the material (coating with nanometrically structured particles) prepared by different methods, granulation, etc.). Fluidization of the material appears to be a very important and efficient process modification method ensuring the improvement especially of fluidity in transport and handling systems [5,6,7]. 
In this work it will be presented an example of modeling the expansion and bed pressure drop of the cohesive and problematic material - titanium dioxide modified by Aerosil R972 in program Ansys / CFX - Fluent using two multiphase models, Euler Fluid-Granular Model and Dense Discrete Phase Model at certain predefined conditions in a square section fluidized bed cell [8-13].

\section{FLUIDIZATION PROCESS}

The behaviour of particle systems during fluidization is quite unique and it is possible to observe a number of interesting phenomena applicable in industrial practice [14] as well as a material processing [15-20]. Research in the field of particle system fluidization in a rotating fluidized bed as opposed to conventional fluidized beds is important for understanding the behavior of centrifugal systems widely used in filtration, drying and centrifugal separation. The behavior of the fluidized particle structures is dependent on the particle size and the difference in density of the fluidized particles and the medium.

\subsection{Modeling fluidization using multi-phase models}

In modeling fluidization within a fluidized bed, it is presumed that it is a non-stationary simulation, multiphase models are used for calculation. In this case of fluidization modeling, two multiphase models were used. Those are: Euler Fluid-Granular Model (EFG) and Dense Discrete Phase Model (DDPM). The aim of the simulation is to determine bed pressure drop, particle concentration in volume and the velocity field of solid particles.

The settings for the geometry of the beds with various cross-sections (plan views) such as a circle and a regular three, four, five, six, and seven-sided polygon were simplified for the benefit of computational power. A circular bed cross-section (plan view) can be replaced by a periodic section of 3D geometry or axially symmetrical 2D geometry. The fluidized bed with a regular $n$-angle cross-section (plan view) can be replaced by a periodic section of 3D geometry. The distributor made of fabric can be defined as a porous material, and the porous material can be replaced by a porous medium in the form of a single cell zone series. The computational geometry will then begin above the distributor and end above the top fabric representing the filter. The fabric of the distributor and filter is of the same porous material.

\subsection{Calculation setup - model theory}

General settings were made for both $2 \mathrm{D}$ and 3D space, in both cases with double precision, and where flow was kept as non-stationary. To determine whether it was turbulent or laminar flow, it was necessary to determine the Reynolds number $R_{e}$ from the hydraulic diameter $D$, the viscosity of the carrier medium $\mu=$ $1.51 \cdot 10^{-5} \mathrm{~Pa}$.s and carrier flow rates $v$. The hydraulic diameter for a cell with a cylindrical area is equal to the diameter of the cell, $D=40 \mathrm{~mm}$. The inlet air velocity is calculated from the air flow rate, which is $Q=0.84$ $\mathrm{m}^{3} / \mathrm{h}$.

$v=\frac{Q}{3600 S}=\frac{Q}{3600 \frac{\pi D^{2}}{4}}=0.1857(\mathrm{~m} / \mathrm{s})$

$R_{e}=\frac{v D}{\mu}=491.92$

$R_{e}<2300$ it is therefore laminar flow.

\subsection{Modeling parameters and properties of $\mathrm{TiO}_{2}$ modified with $\mathrm{SiO}_{2}$ Aerosil $\mathrm{R} 972$}

$\mathrm{SiO}_{2}$ Aerosil R972 (Table 1) depicted in Figure $\mathbf{1}$ a) is commonly used as an additive in silicone sealants, and also contributes to their durability. In combination with problematic cohesive powders it also improves their flowability and prevents the characteristic sintering of the powders during storage [15]. Hydrophobic silica Aerosil R972 has a specific surface area of $130 \mathrm{~m}^{2} / \mathrm{g}$ (Table 1) and that is why it was chosen for investigating the possible improvement in titanium dioxide fluidity. Basic material properties are listed in Table 2. Titanium 
white was modified with Aerosil R972 during processing by mixing on a vibration grid and subsequent inputs were used for modeling fluidization states.

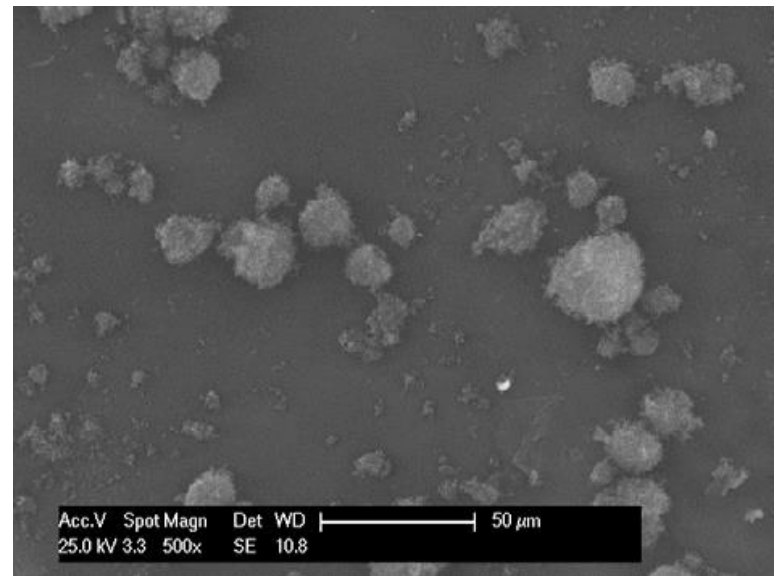

a)

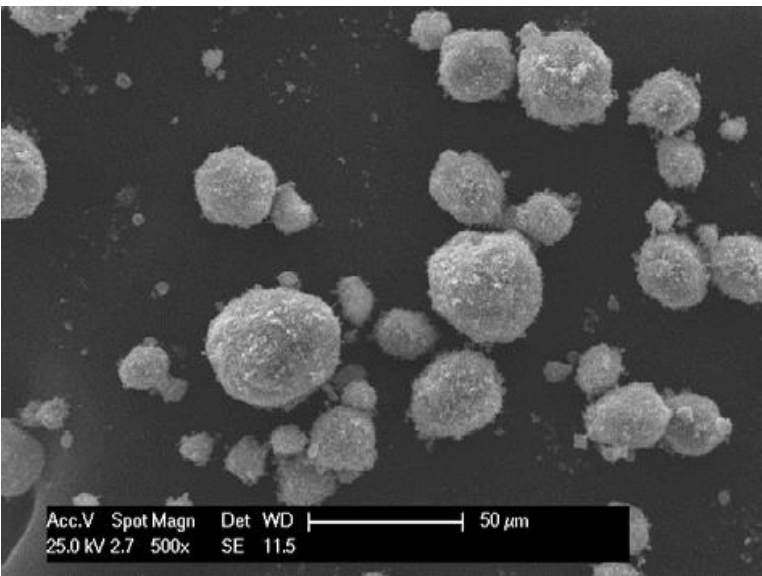

b)

Figure 1 Scanning electron microscopy image of a) silica particles, b) $\mathrm{TiO}_{2}$ [14]

Table 1 Defined physical and chemical properties of R972 silica, taken from Evonik Industries AG, Production formation AEROSIL R972

\begin{tabular}{|l|c|}
\hline Description of Aerosil R972 & Value \\
\hline Specific surface area (BET) (m²/G): & $90-130$ \\
\hline pH value in 4\% dispersion: & $3.6-5.5$ \\
\hline Loss on drying 2 hours at $105^{\circ} \mathrm{C}$ & $\leq 0.5$ \\
\hline Tamped density ISO $787-11$, modified approx.(g/l): & 50 \\
\hline $\mathrm{SiO}_{2}$ content based on ignited material $(\%)$ & 99.8 \\
\hline
\end{tabular}

Table 2 Mechanical and physical properties of the investigated $\mathrm{TiO}_{2}$ material, detected in Laboratory of Institute of Transport, FS, VSB - TU Ostrava

\begin{tabular}{|l|c|}
\hline Material description of $\mathrm{TiO}_{2}$ & Value \\
\hline Average particle size $(\mu \mathrm{m}):$ & 0.63 \\
\hline Angle of internal friction $\left(^{\circ}\right):$ & 45.8 \\
\hline Porosity: & 0.8 \\
\hline Bulk coefficient: & 0.164 \\
\hline Bulk density $\left(\mathrm{kg} / \mathrm{m}^{3}\right):$ & $795-884$ \\
\hline Bulk weight $\left(\mathrm{N} \mathrm{m}^{3}\right):$ & $7.8-8.7 \cdot 10^{3}$ \\
\hline Coefficient of internal friction: & 1.03 \\
\hline pH value: & $6-8$ \\
\hline Whiteness $(\%):$ & 97 \\
\hline
\end{tabular}

\subsection{EFG Model}

In this multi-phase model in Table 3, the primary (continuous) phase was air, the secondary (dispersed) phase was the solid material $\left(\mathrm{TiO}_{2}\right)$ modified with the properties of Aerosil R972. Transport equations are solved for both phases. Both phases have their volume. When the calculation is initialized, the volume fraction of the secondary phase $\left(\mathrm{TiO}_{2}\right)$ is defined. The primary phase (air) is added to 1 . 
Table 3 Model parameters, calculation settings, boundary and boundary conditions and material properties

\begin{tabular}{|c|c|}
\hline \multicolumn{2}{|c|}{ Model parameters } \\
\hline Space dimension: & $2 \mathrm{D} / 3 \mathrm{D}$ \\
\hline Precision: & double \\
\hline Flow: & non-stationary, Incompressible \\
\hline Models: & laminar, EFG for non-stationary flow \\
\hline \multicolumn{2}{|c|}{ Calculation settings } \\
\hline Type: & pressure based \\
\hline Coupling: & simple \\
\hline Volume Fraction: & quick \\
\hline Momentum: & $2^{\text {nd }}$ order \\
\hline Gradient: & green-Gauss Node-based \\
\hline Volume fraction: & 0.4 \\
\hline Time stepping method: & fixed \\
\hline Time step size: & $2 \cdot 10^{-3}$ \\
\hline Max iterations / time step: & 30 \\
\hline \multicolumn{2}{|c|}{ Operating conditions } \\
\hline Pressure $(\mathrm{Pa})$ : & 101325 \\
\hline Gravity $\left(\mathrm{m} / \mathrm{s}^{2}\right)$ : & 9.81 \\
\hline \multicolumn{2}{|c|}{ Material properties } \\
\hline Material: & Air \\
\hline Density $\left(\mathrm{kg} / \mathrm{m}^{3}\right)$ : & 1.2 \\
\hline Dynamic viscosity $(\mathrm{kg} / \mathrm{ms})$ : & $1.8 \cdot 10^{-5}$ \\
\hline Max. volume fraction in bed: & 1 \\
\hline
\end{tabular}

a)

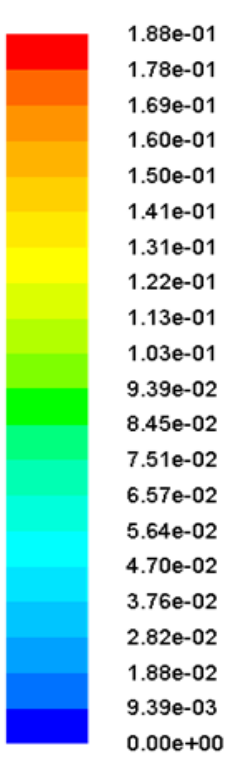

b)
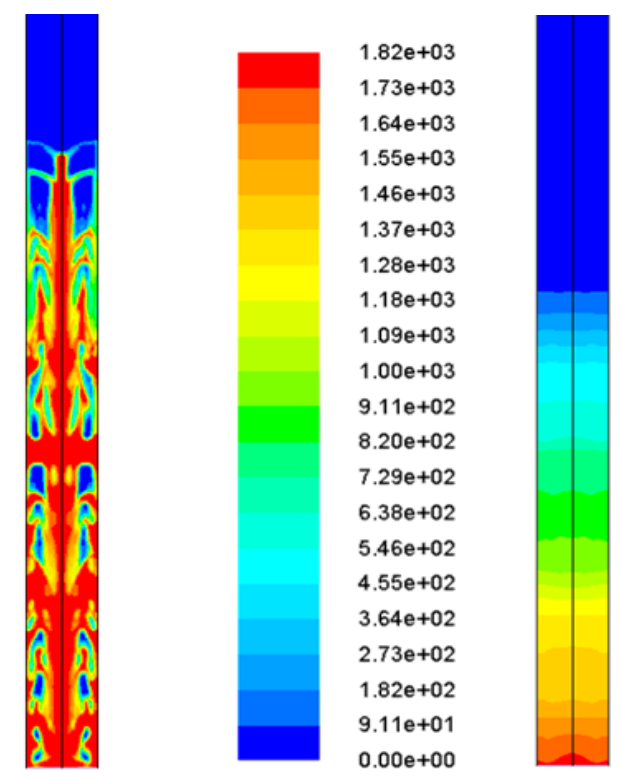

Figure 2 EFG model - titration of volume fraction of the titanium white a) contour of the pressure $(\mathrm{Pa})$; b) [14]
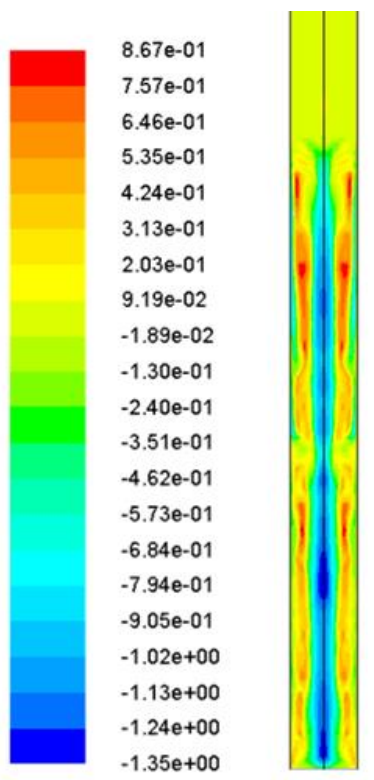

Figure 3 EFG model - Patters of axial velocity of titanium white in $\mathrm{m} / \mathrm{s}$ (contour plot) [14] 
The model was set up by modeling a bed dose of $300 \mathrm{~g}$ for a circular cell with a flow rate of $Q=0.84 \mathrm{~m}^{3} / \mathrm{h}$. From Figure2 on the right one can see a longitudinal section of a circular whole, in which the pressures are color-coded and depicted by contours. From the scale of the legend, the maximum pressure can be read, which is colored red and also represents the pressure drop in the system. The pressure drop determined by numerical modeling is $\Delta P=1820 \mathrm{~Pa}$. It differs from the measured pressure drop $\Delta P=2204 \mathrm{~Pa}$ and the calculated pressure drop $\Delta P=2230 \mathrm{~Pa}$, which can be caused by several input quantities, such as the resistance coefficient in the calculation, which is difficult to define when setting the calculation model. Another factor that must be defined and considered is the wall function, which in our case was set as a "no-slip" for both the gas and the particles themselves. Figure $\mathbf{3}$ shows a plot of the axial velocities of titanium white for the circular cell under consideration and the defined conditions.

\subsection{DDP Model}

a)

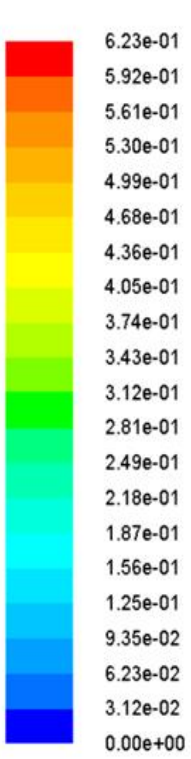

b)

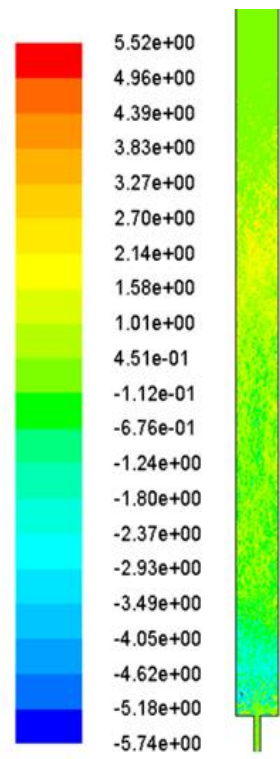

Figure 4 Patterns of a) the titanium dioxide bulk fraction and b) the axial velocity patterns of the titanium dioxide in the DDP model in $\mathrm{m} / \mathrm{s}$ [14]

Transport equations are solved only for the primary phase. The forces acting on the secondary phase (discrete particles - $\mathrm{TiO}_{2}$ are calculated from the primary phase flow modified with Aerosil R972). In the results, the discrete phase trajectories are calculated with the reverse impact of the primary flow. The secondary phase does not have its own volume. Initializing the calculation creates a file with information about the initial state and amount of discrete particles. Figure 4 shows the contours of the titanium dioxide bulk fraction on the left and the axial velocity contours of the titanium dioxide in the DDP model.

\section{CONCLUSION}

The results of the expansion and pressure drop calculations of the cohesive material bed showed that in a cell with a regular hexagonal section, the experimentally measured value of bed pressure drop for $500 \mathrm{~g}$ of $\mathrm{TiO}_{2}$ and flow rate $Q=0.6 \mathrm{~m}^{3} / \mathrm{h}$ is equal to $\Delta P=3742 \mathrm{~Pa}$, the calculated bed pressure drop value for this cell is equal to $\Delta P=3743 \mathrm{~Pa}$. Therefore, the calculated value differs from the experimentally determined value by 1 $\mathrm{Pa}$. Between the experimentally determined pressure drop $(\Delta P=2947 \mathrm{~Pa})$ and pressure drop calculated $(\Delta \mathrm{P}$ $=2947 \mathrm{~Pa}$ ) there was a match for the cell with a pentagonal section into which $400 \mathrm{~g}$ of the Aerosil R972 
modified $\mathrm{TiO}_{2}$ was inserted at air flow $\mathrm{Q}=0.6 \mathrm{~m}^{3} / \mathrm{h}$. The calculated values were very close to the experimental values and it was found that for some cells a smaller air flow was sufficient for the same dose than for others. A triangular-sized cell in all cases needs the greatest amount of air flow for aeration, while a seven-sided or circular cell in most cases needs the least amount of air required for aeration. In Ansys / CFX - Fluent, models were created using two multiphase models, the Euler Fluid-Granular Model (EFG) and the Dense Discrete Phase Model (DDPM). The simulation determined the bed pressure drop, particle concentration in volume and the velocity field of solid particles.

\section{ACKNOWLEDGEMENTS}

\section{The paper has been done in connection with project SP2021/53 Student Grant Competition - Research in Transport.}

\section{REFERENCES}

[1] AN, K., ANDINO, J.M. Enhanced fluidization of nanosized $\mathrm{TiO}_{2}$ by a microjet and vibration assisted (MVA) method. Powder Technology. [online]. 2019, vol. 356, pp. 200-207. Available from:

https://doi.org/10.1016/j.powtec.2019.08.011.

[2] LIN, C.H., CHENG, W.T., DU, S.W. Numerical prediction on the variation of temperature in the eroded blast furnace hearth with titanium dioxide in hot metal. In: International Communications in Heat and Mass Transfer. [online]. 2009, vol. 36, no. 4, pp. 335-341. Available from: https://doi.org/10.1016/j.icheatmasstransfer.2008.11.013.

[3] SLIVA, A., SAMOLEJOVA, A., BRAZDA, R., ZEGZULKA, J., POLAK, J. Optical parameter adjustment for silica nano and micro-particle size distribution measurement using master sizer 2000. Microwave and Optical Technology. [online]. 2003, vol. 5445, pp. 160-163. Available from: https://doi.org/10.1117/12.558761.

[4] DVORSKY, R., LUNACEK, J., SLIVA, A., SANCER, J. Preparation of silicon nanoparticular nanocomposite with thin interparticular tin matrix. Journal of Nanoscience and Nanotechnology. [online]. 2011, vol. 11, no. 10, pp. 9065-9071.

[5] KAO, J., PFEFFER, R., TARDOS, G.I. On partial fluidization in rotating fluidized beds. AIChE journal. [online]. 1987, vol. 33, no. 5, pp. 858-861. Available from: https://doi.org/10.1002/aic.690330520.

[6] CADORET, L., ROSSIGNOL, C., DEXPERT-GHYS, J., CAUSSAT, B. Chemical vapor deposition of silicon nanodots on $\mathrm{TiO}_{2}$ submicronic powders in vibrated fluidized bed. Materials Science and Engineering: $B$. [online]. 2010, vol. 170, no. 1-3, pp. 41-50. Available from: https://doi.org/10.1016/j.mseb.2010.02.024.

[7] SUNOL, A., CARVALLO, R., SMELTZER, B. Nano layer encapsulation using circulating supercritical fluid fluidized bed. Clean Technologies and Environmental Policy. 2015, vol. 17, no. 7, pp. 1831-1836.

[8] Li, H., TONG, H. Multi-scale fluidization of ultrafine powders in a fast-bed-riser/conical-dipleg CFB loop. Chemical Engineering Science. [online]. 2004, vol. 59, no. 8-9, pp. 1897-1904. Available from:

https://doi.org/10.1016/j.ces.2004.01.041.

[9] MACHAC, I., SISKA, B., LECJAKS, Z., BENA, J. Fluidization of spherical particle beds with non-Newtonian fluids in columns of rectangular cross-section. Chemical Engineering Science. 1997, vol. 52, no. 19, pp. 3409-3414.

[10] MARTIN, V., ROMERO-DIEZ, R., RODRÍGUEZ-ROJO, S., COCERO, M.J. Titanium dioxide nanoparticle coating in fluidized bed via supercritical anti-solvent process (SAS). Chemical Engineering Journal. [online]. 2015. vol. 279, pp. 425-432. Available from: https://doi.org/10.1016/j.cej.2015.05.014.

[11] MATSUDA, S., HATANO, H., TSUTSUMI, A. Ultrafine particle fluidization and its application to photocatalytic NOx treatment. Chemical Engineering Journal. [online]. 2001, vol. 82, no. 1-3, pp. 183-188. Available from: https://doi.org/10.1016/S1385-8947(00)00339-9.

[12] QIAN, G. H., BAGYI, I., BURDICK, I.W., PFEFFER, R., SHAW, H., STEVENS, J.G. Gas-solid fluidization in a centrifugal field. AIChE Journal. [online]. 2001, vol. 47, no. 5, pp. 1022-1034. Available from: https://doi.org/10.1002/aic.690470509. 
[13] AHMED, S., SERAJI, M.T., JAHEDI, J., HASHIB, M.A. CFD simulation of turbulence promoters in a tubular membrane channel. Desalination. [online]. 2011, vol. 276, no. 1-3, pp. 191-198. Available from: https://doi.org/10.1016/j.desal.2011.03.045.

[14] PROCHAZKA, A. Fluidization research in transport and storage systems. Dissertation. 2015. (in Czech)

[15] CEP, R., JANASEK, A., SLIVA, A., NESLUSAN, M., BINDER, M. Experimental tool life tests of indexable inserts for stainless steel machining. Tehnicki vjesnik-technical gazette. 2013, vol. 20, no. 6, pp. 933-940.

[16] OUJEZDSKY, A., SLIVA, A., BRAZDA R. Using ICT in education: measuring systems interfaced to computers. In 9th International technology, education and development conference. INTED Proceedings, 2016, pp. 7509-7512. ISBN:978-84-606-5763-7.

[17] BROŽOVÁ, S., INGALDI, M., ŠPERLÍN, I. Economical aspects of high-temperature heating utilization for industrial waste treatment. In: Metal 2013: $22^{\text {nd }}$ International conference on metallurgy and materials. ISBN: 978808729441-3.

[18] KARDAS, E., BROŽOVÁ, S., PUSTĚJOVSKÁ, P. The evaluation of efficiency of the use of machine working time in the industrial company - case study. Management systems in production engineering. [online]. 2017, vol. 25, no. 4, pp. 241-245. Available from: https://doi.org/10.1515/mspe-2017-0034. ISSN: 2450-5781.

[19] BROŽOVÁ, S., DRÁPALA, J., KURSA, M., PUSTĚJOVSKÁ, P., JURSOVÁ, S. Leaching refuse after sphalerite mineral for extraction zinc and cobalt. Metalurgija. 2016, vol. 55, no. 3, pp. 497-499. ISSN 0543-5846.

[20] JONŠTA, P., VÁŇOVÁ, P., BROŽOVÁ, S., PUSTĚJOVSKÁ, P. Hydrogen embrittlement of welded joint made of supermartensitic stainless steel in environment containing sulfane. Archives of Metallurgy and Materials. [online]. 2016, vol. 61, no. 2A, pp. 709-711. Available from: https://doi.org/10.1515/amm-2016-0121. 